\title{
Evaluation of Hemato-Biochemical Parameters, Body and Organ Weight and Reproductive Profile Changes in Response to Receiving Different Lev- els of Indomie Noodles in Albino Rats
}

PINAR KHALID KHUDHUR*, SHEREEN ISMAIL HAJEE ${ }^{1}$,SAMAN MUHSIN ABDULKAREEM ${ }^{2}$ AND LAJAN QASIM RAHMAN

Microbiobiology Unit, Basic Science Department, College of Medicine, Hawler Medical University, Kurdistan Region, Iraq, ${ }^{1}$ Biophysics Unit, Basic Science Department, College of Medicine, Hawler Medical University, Kurdistan Region, Iraq, ${ }^{2}$ Department of Biology, College of Education, Salahaddin University-Erbil, Kurdistan Region, Iraq

Khudhur et al.: Evaluation of Hemato-Biochemical Parameters of Indomie Noodles

The Indomie noodles are an instant noodle sold dried in packets or cups. The noodles are quick and easy to make and can be eaten as a snack or part of the main meal. This study was designed to examine the possible effect of different levels of Indomie noodles on the hematological biochemical profile, organosomatic index and male fertility indices in healthy adult albino rats. In an experimental study, twenty male rats of average weight $\mathbf{1 1 5} \mathbf{g}$ (divided into four groups) and twenty female rats of average weight $100 \mathrm{~g}$ (divided into four groups). Each group consists of five rats. Group $\mathrm{A}$ is the control group and was fed with standard rat feed. In contrast, groups B, C and D were supplied with $25 \%, 50 \%$ and $75 \%$ Indomie instant noodles cooked and spiced with the seasoning. The administration was carried out for $8 \mathrm{w}$. The result showed that the body weight, expressed as growth rate, showed that rats exposed to the $75 \%$ Indomie noodle formulated diets had significantly minimum growth rates than controls and other two different groups. There was a significant increase $(p<0.05)$ in the organosomatic index (kidney, liver, brain and testes) of rats fed on a diet containing $75 \%$ Indomie noodles. There was a significant $(p<0.05)$ increase in lymphocytes percentage, with a decrease in monocytes and granulocyte percentages compared to the control group. Red blood cell indices examination showed a reduction in mean cell volume, mean cell hemoglobin and mean cell hemoglobin concentration value. A diet containing $75 \%$ Indomie noodles appeared to the highest significant decrease in total serum protein and serum uric acid with a significant increase of alkaline phosphatase and blood urea at $25 \%, 50 \%$ and $75 \%$ in comparison to the control group. However, aspartate aminotransferase results show a significant difference at $75 \%$ compared to $0 \%$. On the other, evaluation of various sperm parameters showed there was a significant reduction in sperm concentration, motility and viability between treated groups in comparison to the untreated group in response to an increase in the percent of Indomie noodles in the diet and their plasma testosterone levels of the treated groups decreased insignificantly than those of the control group.

Key words: Indomie noodles, weight gain, lipid profile, liver, renal function enzymes

Instant noodles were first produced in Japan in 1958. They had become popular among people around the world, both in developed and developing countries. According to a 2008 survey, it was found that the annual consumption of instant noodles in the world averaged about 94 billion cups ${ }^{[1]}$. Indomie is a brand of instant noodles by Indofood, the world's largest instant noodle manufacturer, located in Indonesia. Indofood is one of the world's largest manufacturers of dried instant noodles based in Indonesia. The Indomie (the name derived from the Indonesian Mi Goreng, which means fried noodles) is an instant noodle sold dried in packets or cups. The noodles are quick and easy to make and can be eaten as a snack or part of the main meal. Their versatility means that people can carry them to work or on trips and cook them just by adding hot water from a kettle ${ }^{[2]}$. Indomie noodles with its seasoning are usually prepared for consumption. Therefore, the rate at which Indomie noodles are consumed is proportional to the rate at which the seasoning is consumed. The principal constituents of Indomie noodle are wheat flour, vegetable oil, iodized salt, sodium polyphosphate,

*Address for correspondence

E-mail: pinar.khudhur@med.hmu.edu.krd 
sodium carbonate, potassium carbonate, guar gum and tartrazine, while that of the seasoning powder is iodized salt, monosodium glutamate (MSG, E-621), hydrolyzed vegetable protein, soy powder, garlic powder, chicken flavour and chili powder ${ }^{[3]}$.

The result obtained by Ejembi, Sanni ${ }^{[2]}$ showed that Indomie noodle of $120 \mathrm{~g}$ pack contained $2.60 \mathrm{~g}$ of moisture, $0.50 \mathrm{~g}$ of ash, $0.20 \mathrm{~g}$ crude fiber, $24.00 \mathrm{~g}$ fats, $12.69 \%$ proteins and $60.01 \%$ of carbohydrates per serving. Indomie noodles also contain tartrazine (otherwise known as E102) as a synthetic lemonyellow azo dye used as a food colouring. It is water soluble and has a maximum absorbance in an aqueous solution. Tartrazine consists of an azo $(-\mathrm{N}=\mathrm{N}-)$ group, which is very harmful to living things $\mathrm{s}^{[4]}$. The constituents of noodles have been implicated in causing teratogenic or carcinogenic changes in rats $^{[5]}$. Industrial food manufacturers market MSG as a flavour enhancer because it balances, blends and rounds the total perception of other tastes ${ }^{[6]}$. The instant noodles manufacturing process usually makes use of the application of various substances like sodium, oxidized fat and oil (during instant frying), which might be detrimental to health. Previously reported that MSG have caused a various health hazard, including liver ${ }^{[7]}$, kidney damage ${ }^{[8]}$ and a toxic effect on the testis; the toxic effect on the testes caused by producing a significant oligozoospermia and increases abnormal sperm morphology in a dose dependent fashion in male Wistar rats ${ }^{[9]}$. It has been implicated in male infertility by causing testicular hemorrhage, degeneration and alteration of sperm cell population and morphology ${ }^{[10]}$. MSG also caused a reduction in the sperm count ${ }^{[11]}$. The present study was designed to examine the possible effect of different levels of Indomie noodles on the hematological biochemical profile, organosomatic index in healthy adult female albino rats and male fertility indices in healthy adult albino rats.

\section{MATERIALS AND METHODS}

\section{Study design and animals population:}

Healthy adult female albino rats, weighing about $100 \mathrm{~g}$ (90 d) and healthy adult male albino rats, weighing about $115 \mathrm{~g}$ (90 d) provided from the animal house in the Department of Biology, College of Education, Salahaddin University-Erbil. The rats were housed in clean polypropylene cages, maintained in an air conditioned animal house with a constant photo period of $12 \mathrm{~h} \mathrm{light/dark} \mathrm{cycle} \mathrm{(lights} \mathrm{on} \mathrm{at} \mathrm{6:00} \mathrm{a.m.).} \mathrm{They}$ were fed with pellet diet and drinking water ad libitum.
The female rats were divided into four groups, 5 in each: A, B, C and D. Group A is the control group and was fed with normal rat feed, while groups B, C and D were supplied with $25 \%, 50 \%$ and $75 \%$, respectively and the male rats were divided into four groups, 5 in each: A, B, C and D. Group A is the control group and was fed with standard rat feed, while groups B, C and $\mathrm{D}$ were fed with $25 \%, 50 \%$ and $75 \%$, respectively Indomie instant noodles cooked and spiced with the seasoning. Feeding was done for $8 \mathrm{w}$.

On the 56th $d$, the rats were sacrificed. Blood samples were collected by withdrawing the blood from the right ventricle of the heart for hematological, biochemical and hormonal assays. About $2 \mathrm{ml}$ of blood was collected in tubes containing Ethylenediamine tetraacetic acid (EDTA) as an anticoagulant for hematological analysis using a fully automated 3 part differential hematology analyzer. However, about $5 \mathrm{ml}$ of blood was collected in a gel tube then allowed to stand at room temperature for 10-15 min. The serum collected was then gently separated by centrifuging at $3500 \mathrm{rpm}$ for $15 \mathrm{~min}$; the serum obtained was stored at $-20^{\circ}$ until it was used for biochemical and hormonal assays.

\section{Indomie noodles:}

Cartons of one mostly consumed variety (normal size consists of $70 \mathrm{~g}$, containing $7 \mathrm{~g}$ seasoning) of a popular Indomie noodle (Indomie instant noodles, Kingdom of Saudi Arabia (KSA)) were obtained from a supermarket in Erbil, Kurdistan Region-Iraq. The ingredients contained in the Indomie noodles were: wheat flour, vegetable oil, iodized salt, sodium polyphosphate, sodium carbonate, potassium carbonate, guargum, tartrazine and antioxidant (Tert-butylhydroquinone (TBHQ)). The seasoning powder (spices) contains iodized salt, MSG (621), sugar, hydrolyzed vegetable protein, soy powder, pepper, garlic powder and chicken flavour.

\section{Bodyweight, weight gain and organosomatic index of experimental rats:}

Bodyweight changes were recorded every week throughout the experiments. Bodyweight gain and vital organs of experimental rats were weighed at the end of treatment. The liver, brain, testes, right and left kidneys were removed and weighed to measure the organosomatic index (organ weight $\times 100 /$ body weight).

\section{Evaluation of complete blood count:}

Complete blood count includes hemoglobin $(\mathrm{Hb})$, 
packed cell volume (PCV), total red blood corpuscles (RBC), the total count of white blood cells (WBC), differential count, platelets count, $\mathrm{RBC}$ indices such as mean cell volume (MCV), mean cell hemoglobin $(\mathrm{MCH})$ and mean cell hemoglobin concentration (MCHC) were analyzed by ABX Micro ES60, Horiba, a fully automated 3 part differential hematology analyzer.

\section{Determination of biochemical tests:}

COBAS INTEGRA 400 plus system, fully automated biochemical analyzer (Germany) was used to determine the concentrations of the following biochemical parameters in rats sera of control and experimental grouped rats.

\section{Lipid profile test:}

Cholesterol, Triglycerides (TGs) and high-density lipoprotein (HDL) cholesterol analyses are performed on a COBAS INTEGRA 400 plus system analyzer, which is serviced by Roche Diagnostics (Deutschland). Cholesterol is measured enzymatically using the cholesterol high performance reagent (cat. no. 80106), BIOLABO, France. TGs are analyzed enzymatically, simultaneously with cholesterol using reagents from the same manufacturer (TGs/glycerol phosphate oxidase (GPO), cat. no. 80019). Direct HDL cholesterol reagent is obtained from Centronic $\mathrm{GmbH}$, Wartenberg, Germany (Direct HDL, cat. no. CF09000100) and analyzed simultaneously with cholesterol and TGs. Low-density lipoprotein cholesterol (LDL-C) was calculated using the Friedewald equation ${ }^{[12]}$, as shown in the following:

LDL Cholesterol=total serum cholesterol- $($ HDL + total $\mathrm{TG} / 5) \mathrm{mg} / 100 \mathrm{ml}$

\section{Fasting blood sugar:}

Glucose activity of serum was assayed by using a commercial kit (BIOLABO, France, cat. no. 87409).

\section{Renal function test:}

Urea activity of serum was assayed by using a commercial kit (BIOLABO, France, cat. no. 80021). Creatinine activity of serum was assayed by using a commercial kit (BIOLABO, France, cat. no. 80107). The serum's uric acid activity was assayed by using a commercial kit (BIOLABO, France, cat. no. 80001).

\section{Liver function test:}

Total serum bilirubin (TSB) activity of serum was assayed by using a commercial kit (BIOLABO, France, cat. no. 80403). Alkaline phosphatase (ALP) activity of serum was assayed by using a commercial kit (NS, BIOTECH, cat. no. 0520). Alanine transaminase (ALT) and aspartate aminotransferase (AST) activities were assayed by using a commercial kit (NS, BIOTECH, cat. no. 02100). The serum's total protein activity was assayed by using a commercial kit (BIOLABO, France, cat. no. LP87016).

\section{Spermatological evaluation:}

Cauda epididymis was separated from caput and corpus regions, weighed and suspended in $2 \mathrm{ml}$ of phosphate buffer saline (PBS, pH 7.2) at $37^{\circ}$. The epididymal fluid was collected in PBS by giving cuts to the cauda epididymis and sperm enriched epididymal fluid was collected in a tube. The spermatozoa were analyzed for their motility, concentration, viability and abnormalities.

\section{Sperm motility:}

The motility of sperm was evaluated directly after mincing in a drop of sperm suspension, microscopically. A drop of sperm suspension under the coverslip was examined for motility at 400x and percent motility was calculated. About 200 motile and non-motile spermatozoa were observed using an Olympus microscope. Sperm motility was expressed as a percent of motile sperm of the total sperm counted ${ }^{[13]}$.

\section{Sperm concentration:}

The sperm concentration was carried out by diluting the sperm suspension with PBS (1:20) using a WBC diluting pipette, then mixed. After that, a drop of them was delivered into the Neubauer hemocytometer on each side of the counting chamber. The hemocytometer is allowed to stand for 5 min for sedimentation ${ }^{[14]}$, then sperms were counted in large eight squares of $1 \mathrm{~mm}^{2}$ each area except the central erythrocyte counting area of Neubauer's chamber was performed and multiplied by a $5 \times 10^{4}$ factor to calculate the total number of sperms.

\section{Sperm viability percentage:}

The live/dead ratio was determined using $1 \%$ Eosin and $5 \%$ Nigrosin in $3 \%$ sodium citrate dehydrate solution according to the method described by Wells and $\mathrm{Awa}^{[15]}$.

\section{Sperm abnormalities:}

About 100 spermatozoa were observed under a microscope for changes in sperm morphology, 
according to the method of Feuston, Bodnar ${ }^{[14]}$.

\section{Plasma testosterone assay:}

The serum level of testosterone was determined by the enzyme-linked immunosorbent assay (ELISA) technique by use DRG ELISA testosterone (ELISA EIA-1559, 96 wells; DRG Instruments, GmbH, Marburg, Germany).

\section{Statistical analysis:}

Data are expressed as the mean \pm standard deviation (SD). Analysis of results was performed by one way analysis of variance (ANOVA) followed by Tukey's multiple comparisons test to determine significant differences between the experimental groups using GraphPad Prism 6 version 7.01 for Windows (Graph Pad Software 2012). Mean values were considered to be statistically significant at $\mathrm{p}<0.05^{[16]}$.

\section{RESULTS AND DISCUSSION}

The body weights at the beginning of the experimental period and after $8 \mathrm{w}$ of all experimental groups are demonstrated in Table 1. A gradual increase in the body weight of normal control rats $(105.73 \%$ in males and $61.80 \%$ in females) and those exposed to $25 \%$ Indomie noodles ( $70.03 \%$ in males and $61.27 \%$ in females), 50 $\%$ Indomie noodles $(70.93 \%$ in males and $56.82 \%$ in females) and $75 \%$ Indomie noodles (48.87\% in males and $25.08 \%$ in females) was recorded compared with their initial body weights. The statistical analysis of body weight, expressed as growth rate, showed that rats exposed to the $75 \%$ Indomie noodle formulated diets had significantly minimum growth rates than controls and other two different groups.
The effects of Indomie noodle formulated diet on the organ body weight ratio (organosomatic index) of albino female rats are shown in Table 2 and male rats are shown in Table 3. The data presented in Table 2 showed that there was an insignificantly increase $(p<0.05)$ in the organ weight of the liver (hepatosomatic index) in the group given $50 \%$ and $75 \%$ Indomie noodles compared to control. Also in Table 3 it shows that there was no significant variation in organosomatic index between group A $(0 \%)$ with the groups which processed with 25 $\%$ and $50 \%$ (group B and C) from Indomie noodles in the brain, liver, kidney and testes. Whereas there was a significant difference $(\mathrm{p}<0.05)$ between group A $(0 \%)$ of male rats in organs (brain and testes) compared with group D, which administered $75 \%$ Indomie noodles in the organosomatic index and a significant increase $(p<0.05)$ in the organ weight of the right and left kidney in the group fed with $50 \%$ and $75 \%$ Indomie noodle supplemented diet shown in Table 2.

Hematological parameters between control and experimental groups in female rats are compared in Table 4. There was no significant difference between both $0 \%$ and $25 \%$ of all presented parameters, whereas a significant difference in $50 \%$ for parameters: lymphocytes percentage, monocytes percentage, granulocytes percentage and platelets $(109 / \mathrm{L})$ which is $87.50 \pm 0.81,7.85 \pm 0.53,4.65 \pm 0.28$ and $590.50 \pm 18.73$, respectively. On the other hand, the group of 75 $\%$ showed a significant difference for the last four parameters $\mathrm{MCV}, \mathrm{MCH}, \mathrm{MCHC}$ and platelets, which is $53.00 \pm 1.15,18.20 \pm 0.51,34.62 \pm 0.49,799.50 \pm 39.68$, respectively. The rest of the parameters for different groups were not statistically significant, as shown in Table 4.

TABLE 1: EFFECTS OF INDOMIE NOODLE FORMULATED DIET ON BODY WEIGHTS IN MALE AND FEMALE ALBINO RATS

\begin{tabular}{|c|c|c|c|c|c|c|c|c|}
\hline \multirow{3}{*}{ Parameters } & \multicolumn{8}{|c|}{ Mean \pm standard deviation } \\
\hline & \multicolumn{2}{|c|}{ Group A (0 \%) } & \multicolumn{2}{|c|}{ Group B (25 \%) } & \multicolumn{2}{|c|}{ Group C (50 \%) } & \multicolumn{2}{|c|}{ Group D (75 \%) } \\
\hline & Male group & $\begin{array}{l}\text { Female } \\
\text { group }\end{array}$ & Male group & $\begin{array}{l}\text { Female } \\
\text { group }\end{array}$ & Male group & $\begin{array}{l}\text { Female } \\
\text { group }\end{array}$ & Male group & Female group \\
\hline $\begin{array}{l}\text { Initial body } \\
\text { weight (g) }\end{array}$ & $115.25 \pm 04.11$ & $102.75 \pm 2.98$ & $125.5 \pm 07.59$ & $102.25 \pm 6.80$ & $123.25 \pm 09.06$ & $101.50 \pm 3.10$ & $118.5 \pm 9.39$ & $101.75 \pm 4.34$ \\
\hline $\begin{array}{l}\text { Weight gain } \\
\text { (g) }\end{array}$ & $237.25 \pm 13.81$ & $166.25 \pm 4.85$ & $213.2 \pm 11.17^{*}$ & $164.75 \pm 8.42$ & $210.25 \pm 09.74^{*}$ & $159.25 \pm 7.93$ & $176.25 \pm 11.50^{* * *}$ & $127.25 \pm 6.29^{* * *}$ \\
\hline $\begin{array}{l}\text { Weight gain } \\
\text { (\%) }\end{array}$ & $122 \pm 9.83$ & $63.50 \pm 1.91$ & $87.75 \pm 6.18^{* * *}$ & $62.50 \pm 3.00$ & $87 \pm 6.21^{* * *}$ & $57.75 \pm 4.85$ & $57.75 \pm 3.20^{* * *}$ & $25.50 \pm 4.35^{* * *}$ \\
\hline $\begin{array}{l}\text { Weight gain } \\
\text { (\%) }\end{array}$ & $105.73 \pm 5.13$ & $61.80 \pm 0.50$ & $70.03 \pm 5.25^{* * *}$ & $61.27 \pm 3.97$ & $70.93 \pm 8.12^{* * *}$ & $56.82 \pm 3.05$ & $48.87 \pm 3.29^{* * *}$ & $25.08 \pm 4.41^{* * *}$ \\
\hline
\end{tabular}

Significance levels are indicated as follows: ${ }^{* * *}$ indicates significance at the $0.1 \%$ level and ${ }^{*}$ indicates significance at the $5 \%$ level 
TABLE 2: EFFECTS OF INDOMIE NOODLES ON SOME ORGANOSOMATIC INDEX IN FEMALE ALBINO RATS

\begin{tabular}{lcccc}
\hline \multirow{2}{*}{ Parameters } & \multicolumn{4}{c}{ Mean \pm standard deviation } \\
\cline { 2 - 5 } & Group A (0 \%) & Group B (25 \%) & Group C (50 \%) & Group D (75 \%) \\
\hline Hepatosomatic index & $3.73 \pm 0.25$ & $3.89 \pm 0.08$ & $4.00 \pm 0.56$ & $4.29 \pm 0.55$ \\
Renosomatic index (right) & $0.34 \pm 0.01$ & $0.39 \pm 0.02$ & $0.41 \pm 0.03^{*}$ & $0.42 \pm 0.05^{*}$ \\
Renosomatic index (left) & $0.33 \pm 0.01$ & $0.36 \pm 0.02$ & $0.40 \pm 0.02^{*}$ & $0.40 \pm 0.05^{*}$ \\
\hline
\end{tabular}

Significance levels are indicated as follows: *indicates significance at the $5 \%$ level

TABLE 3: EFFECTS OF INDOMIE NOODLES ON THE ORGANOSOMATIC INDEX IN MALE ALBINO RATS

\begin{tabular}{lcccc}
\hline \multirow{2}{*}{ Parameters } & \multicolumn{4}{c}{ Mean \pm standard deviation } \\
\cline { 2 - 5 } & Group A (0 \%) & Group B (25 \%) & Group C (50 \%) & Group D (75 \%) \\
\hline Brainsomatic index & $0.66 \pm 0.10$ & $0.80 \pm 0.15$ & $0.80 \pm 0.10$ & $0.97 \pm 0.17^{*}$ \\
Hepatosomatic index & $3.86 \pm 0.14$ & $3.28 \pm 0.23$ & $3.52 \pm 0.56$ & $3.68 \pm 0.28$ \\
Renosomatic index (right) & $0.43 \pm 0.05$ & $0.41 \pm 0.03$ & $0.40 \pm 0.02$ & $0.43 \pm 0.06$ \\
Renosomatic index (left) & $0.41 \pm 0.05$ & $0.40 \pm 0.06$ & $0.40 \pm 0.03$ & $0.43 \pm 0.05$ \\
Gonadosomatic index (right) & $0.49 \pm 0.08$ & $0.61 \pm 0.07$ & $0.60 \pm 0.05$ & $0.73 \pm 0.13^{* *}$ \\
Gonadosomatic index (left) & $0.49 \pm 0.01$ & $0.61 \pm 0.10$ & $0.60 \pm 0.06$ & $0.68 \pm 0.07^{* *}$ \\
\hline
\end{tabular}

Significance levels are indicated as follows: ${ }^{*}$ indicates significance at the $1 \%$ level and ${ }^{*}$ indicates significance at the $5 \%$ level

TABLE 4: EFFECTS OF INDOMIE NOODLES ON COMPLETE BLOOD COUNT (CBC) IN FEMALE ALBINO RATS

\begin{tabular}{|c|c|c|c|c|}
\hline \multirow{2}{*}{ Parameters } & \multicolumn{4}{|c|}{ Mean \pm standard deviation } \\
\hline & Group A (0 \%) & Group B (25 \%) & Group C (50 \%) & Group D (75 \%) \\
\hline $\begin{array}{l}\text { Leucocytes count } \\
\left(10^{9} / \mathrm{L}\right)\end{array}$ & $6.17 \pm 3.30$ & $6.65 \pm 2.19$ & $6.90 \pm 0.69$ & $8.27 \pm 1.28$ \\
\hline Lymphocytes (\%) & $77.67 \pm 2.75$ & $80.32 \pm 3.60$ & $87.50 \pm 0.81^{* * *}$ & $78.25 \pm 1.91$ \\
\hline Monocytes (\%) & $10.52 \pm 1.13$ & $9.95 \pm 1.55$ & $7.85 \pm 0.53^{*}$ & $9.00 \pm 1.06$ \\
\hline Granulocytes (\%) & $11.80 \pm 2.26$ & $9.72 \pm 2.40$ & $4.65 \pm 0.28^{* * *}$ & $12.75 \pm 0.85$ \\
\hline RBC count $\left(10^{12} / L\right)$ & $5.94 \pm 0.15$ & $6.15 \pm 0.59$ & $6.18 \pm 0.52$ & $6.36 \pm 0.35$ \\
\hline Hemoglobin (g/dl) & $12.07 \pm 0.35$ & $12.35 \pm 0.86$ & $10.75 \pm 1.36$ & $11.52 \pm 0.44$ \\
\hline Hematocrit (\%) & $33.22 \pm 1.03$ & $34.27 \pm 2.15$ & $34.07 \pm 4.10$ & $33.70 \pm 1.39$ \\
\hline$M C V(f l)$ & $55.75 \pm 0.50$ & $56.00 \pm 2.16$ & $54.50 \pm 0.57$ & $53.00 \pm 1.15^{*}$ \\
\hline $\mathrm{MCH}(\mathrm{pg})$ & $20.27 \pm 0.29$ & $20.07 \pm 0.65$ & $19.95 \pm 0.12$ & $18.20 \pm 0.51^{* * *}$ \\
\hline$M C H C(g / d l)$ & $36.30 \pm 0.42$ & $36.05 \pm 0.51$ & $36.65 \pm 0.20$ & $34.62 \pm 0.49^{* * *}$ \\
\hline Platelets $\left(10^{\circ} / \mathrm{L}\right)$ & $672.75 \pm 35.25$ & $638.75 \pm 48.56$ & $590.50 \pm 18.73^{*}$ & $799.50 \pm 39.68^{* *}$ \\
\hline
\end{tabular}

Significance levels are indicated as follows: ${ }^{* * *}$ indicates significance at the $0.1 \%$ level, ${ }^{* * i n d i c a t e s ~ s i g n i f i c a n c e ~ a t ~ t h e ~} 1 \%$ level and *indicates significance at the $5 \%$ level

The data presented in Table 5 showed that female rats fed on a diet containing $75 \%$ Indomie noodles appeared to the highest significant decrease in total serum protein $(5.92 \pm 0.12 \mathrm{~g} / \mathrm{dl})$ than rats fed on a diet containing 25 $\%$ and $50 \%$ Indomie noodles $(6.32$ and $6.30 \mathrm{~g} / \mathrm{dl}$, respectively) compared to rats fed on a diet containing $0 \%$ Indomie noodles $(6.80 \mathrm{~g} / \mathrm{dl})$. Although the mean level of serum glucose, total cholesterol, LDL-C and TG was higher in experimental groups, when added Indomie noodles for their diets and the differences were insignificant.
The effects of different levels of Indomie noodles formulated diet on liver function indices of female rats were demonstrated in Table 6 . The results have been taken from parameters that show that the first one (AST) show significant differences at $75 \%$ (264.50 \pm 19.15$)$, whereas this result is not significant in the other percentage levels. In the ALT and TSB, there is no significant difference in all the percentage levels. However, in the ALP, the results show the significant value at $25 \%, 50 \%$ and $75 \%$, which is $284.75 \pm 10.68$, $342.25 \pm 10.81$ and $397.75 \pm 14.08$, respectively in comparison to the control group (172.25 \pm 11.61$)$. 
www.ijpsonline.com

TABLE 5: EFFECTS OF INDOMIE NOODLES ON SERUM PROTEIN, GLUCOSE AND LIPID PROFILE IN FEMALE ALBINO RATS

\begin{tabular}{lcccc}
\hline \multirow{2}{*}{ Parameters } & \multicolumn{4}{c}{ Mean \pm standard deviation } \\
\cline { 2 - 5 } & Group A (0 \%) & Group B (25 \%) & Group C (50 \%) & Group D (75 \%) \\
\hline Total protein $(\mathrm{mg} / \mathrm{dl})$ & $6.80 \pm 0.08$ & $6.32 \pm 0.25$ & $6.30 \pm 0.40^{*}$ & $5.92 \pm 0.12^{* * *}$ \\
Serum glucose $(\mathrm{mg} / \mathrm{dl})$ & $140.57 \pm 16.31$ & $152.42 \pm 9.73$ & $154.60 \pm 8.69$ & $155.10 \pm 5.30$ \\
Total cholesterol $(\mathrm{mg} / \mathrm{dl})$ & $69.10 \pm 6.15$ & $69.80 \pm 11.29$ & $82.20 \pm 3.49$ & $71.52 \pm 9.49$ \\
HDL cholesterol $(\mathrm{mg} / \mathrm{dl})$ & $75.97 \pm 2.85$ & $76.20 \pm 10.67$ & $75.42 \pm 8.61$ & $75.37 \pm 6.94$ \\
LDL cholesterol $(\mathrm{mg} / \mathrm{dl})$ & $30.30 \pm 7.64$ & $32.05 \pm 6.50$ & $31.30 \pm 1.48$ & $35.75 \pm 6.91$ \\
TGs $(\mathrm{mg} / \mathrm{dl})$ & $119.20 \pm 2.52$ & $119.47 \pm 6.20$ & $119.92 \pm 7.99$ & $134.70 \pm 6.93$ \\
\hline
\end{tabular}

Significance levels are indicated as follows: ${ }^{* * *}$ indicates significance at the $0.1 \%$ level and *indicates significance at the $5 \%$ level

TABLE 6: EFFECTS OF INDOMIE NOODLES ON LIVER FUNCTION TESTS IN FEMALE ALBINO RATS

\begin{tabular}{lcccc}
\hline \multirow{2}{*}{ Parameters } & \multicolumn{4}{c}{ Mean \pm standard deviation } \\
\cline { 2 - 5 } & Group A (0\%) & Group B $(25 \%)$ & Group C (50 \%) & Group D (75 \%) \\
\hline AST (U/L) & $161.50 \pm 8.18$ & $185.00 \pm 18.09$ & $166.75 \pm 16.31$ & $264.50 \pm 19.15^{* * *}$ \\
ALT (U/L) & $60.25 \pm 4.92$ & $64.50 \pm 7.04$ & $62.25 \pm 5.43$ & $63.50 \pm 5.32$ \\
ALP (IU/L) & $172.25 \pm 11.61$ & $284.75 \pm 10.68^{* *}$ & $342.25 \pm 10.81^{* * *}$ & $397.75 \pm 14.08^{* * *}$ \\
TSB (mg/dl) & $1.65 \pm 0.75$ & $2.75 \pm 3.46$ & $2.05 \pm 1.02$ & $0.90 \pm 0.28$ \\
\hline
\end{tabular}

Significance levels are indicated as follows: ${ }^{* * *}$ indicates significance at the $0.1 \%$ level and ${ }^{* *}$ indicates significance at the $1 \%$ level

Results in Table 7 refer to serum creatinine, urea and uric acid in rats fed on a different percentage of Indomie noodles than rats fed on basal diet. Serum creatinine reached a non-significant difference among all the percentage levels while blood urea shows the significant value at $25 \%$ is $51.32 \mathrm{mg} / \mathrm{dl}, 50 \%$ is 52.45 $\mathrm{mg} / \mathrm{dl}$ and $75 \%$ is $52.82 \mathrm{mg} / \mathrm{dl}$ in comparison to 0.0 $\%(43.92 \mathrm{mg} / \mathrm{dl})$. On the other view, serum uric acid shows a non-significant difference in the $25 \%$ level in comparison to the control group, whereas the other two percentage levels (50\% and $75 \%$ ) show a significant difference, which is 2.15 and $2.12 \mathrm{mg} / \mathrm{dl}$, respectively.

Evaluation of various sperm parameters showed there was a significant difference in sperm concentration, motility and viability between these groups, as shown in Table 8 . The average value of sperm concentration of rats in group B (47.80 \pm 2.35$), C(40.15 \pm 3.66)$ and D $(32.65 \pm 6.41)$ were significantly $(\mathrm{p}<0.05)$ lower compare with that of the group A rats $(68.00 \pm 9.69)$. The degree of sperm motility of rats in group A $(0 \%)$ was significantly $(p<0.05)$ higher than what was observed in rats in each of the treatment groups. Sperm viability was insignificantly decreased in rats treated with $25 \%$ and
$50 \%$ of Indomie noodles. The average sperm viability was found to be $88.25 \pm 8.05$ and $85.75 \pm 8.46 \%$ in these groups, respectively. A significant decrease $(\mathrm{p}<0.05)$ in the sperm viability $(74.25 \pm 9.28 \%)$ was observed in rats exposed to $75 \%$ of Indomie noodles when compared with that of the control rats $(92.25 \pm 5.56 \%)$. The results of the present study showed there was an insignificant reduction in the normal sperms $(\mathrm{p}>0.05)$ of the rat that received Indomie noodles compared with the control group. Compared to group A (control group), the plasma testosterone levels were insignificantly lowered in $50 \%$ and $75 \%$ of Indomie noodles, whereas the testosterone levels in rats with $25 \%$ of Indomie noodles were not changed (Table 9).

The minimum body weight gain was noted in rats consuming $75 \%$ Indomie noodle formulated diets $(27.63 \%)$ than the control group $(59.68 \%)$. This minimum increase is an indication that supplementation with Indomie noodles did not support growth because a typical serving of noodles contains a very low amount of protein typically 1-3\% compared to the pellets fed to animals in the control group ${ }^{[17]}$. 
TABLE 7: EFFECTS OF INDOMIE NOODLE FORMULATED DIET ON KIDNEY FUNCTION TESTS IN FEMALE ALBINO RATS

\begin{tabular}{lcccc}
\hline \multirow{2}{*}{ Parameters } & \multicolumn{4}{c}{ Mean \pm standard deviation } \\
\cline { 2 - 5 } & Group A (0 \%) & Group B (25 \%) & Group C (50 \%) & Group D (75 \%) \\
\hline Serum creatinine $(\mathrm{mg} / \mathrm{dl})$ & $1.19 \pm 0.14$ & $1.09 \pm 0.32$ & $1.40 \pm 0.17$ & $1.45 \pm 0.20$ \\
Blood urea $(\mathrm{mg} / \mathrm{dl})$ & $43.92 \pm 3.58$ & $51.32 \pm 4.58 *$ & $52.45 \pm 2.24^{* *}$ & $52.82 \pm 1.65 * *$ \\
Serum uric acid $(\mathrm{mg} / \mathrm{dl})$ & $5.87 \pm 1.79$ & $4.47 \pm 0.54$ & $2.15 \pm 0.20 * *$ & $2.12 \pm 1.22 * *$ \\
\hline
\end{tabular}

Significance levels are indicated as follows: ${ }^{* *}$ indicates significance at the $1 \%$ level and ${ }^{*}$ indicates significance at the $5 \%$ level

TABLE 8: SPERM ANALYSIS OF RATS WITH DIFFERENT LEVELS OF INDOMIE NOODLES

\begin{tabular}{lcccc}
\hline \multirow{2}{*}{ Parameters } & \multicolumn{4}{c}{ Mean \pm standard deviation } \\
\cline { 2 - 5 } & Group A (0 \%) & Group B (25 \%) & Group C (50 \%) & Group D (75 \%) \\
\hline Sperm count $\left(10^{6} / \mathrm{ml}\right)$ & $68.00 \pm 9.69$ & $47.80 \pm 2.35^{* *}$ & $40.15 \pm 3.66^{* * *}$ & $32.65 \pm 6.41^{* * *}$ \\
Sperm motility (\%) & $89.75 \pm 3.77$ & $77.50 \pm 6.24^{*}$ & $65.00 \pm 4.08^{* * *}$ & $52.50 \pm 7.50^{* * *}$ \\
Sperm viability (\%) & $92.25 \pm 5.56$ & $88.25 \pm 8.05$ & $85.75 \pm 8.46$ & $74.25 \pm 9.28^{*}$ \\
Sperm abnormality (\%) & $13.25 \pm 2.62$ & $15.75 \pm 5.90$ & $17.75 \pm 7.18$ & $22.25 \pm 9.03$ \\
\hline
\end{tabular}

Significance levels are indicated as follows: ${ }^{* * *}$ indicates significance at the $0.1 \%$ level, ${ }^{* *}$ indicates significance at the $1 \%$ level and *indicates significance at the $5 \%$ level

TABLE 9: EFFECT OF INDOMIE NOODLES ON TESTOSTERONE LEVELS IN MALE ALBNO RATS

\begin{tabular}{lcccc}
\hline Parameters & \multicolumn{4}{c}{ Mean \pm standard deviation } \\
\cline { 2 - 5 } & Group A (0 \%) & Group B (25 \%) & Group C (50 \%) & Group D (75 \%) \\
\hline Testosterone level $(\mathrm{ng} / \mathrm{ml})$ & $1.54 \pm 1.35$ & $1.52 \pm 1.32$ & $1.01 \pm 0.31$ & $0.38 \pm 0.34$ \\
\hline
\end{tabular}

The organosomatic index was insignificantly changed in treated groups compared to the control group (group A) except in group D in male rats $(75 \%)$ in the brain and testes. An increase in organ-body weight ratio is an indication of inflammation ${ }^{[18]}$. It has been reported that an increase in the liver weight of animals is a common sign of induced toxicity as a result of the induction of liver enzymes, which could be due to a marked proliferation of the smooth endoplasmic reticulum ${ }^{[19]}$. The increase in kidney weight is suggestive of nephropathy ${ }^{[20]}$. Also, as brain tissue swells or shrinks, the cellular transporters activity is approximately changed by the up or down regulations, as reported in the case of hyponatremia or hypernatremia. However, there are many different causes of cell swelling or shrinkage, including drug poisoning, water intoxication, hypoxia and acute hyponatremia. Brain swellings can lead to severe cytotoxic oedema and may lead to a marked reduction in the size of the ventricular system and basal cisterns $^{[21]}$.

There were significant differences $(p<0.05)$ among treatment groups for most of the hematological parameters. The total leucocyte count was not affected by the dietary treatments, thereby indicating that no pathological effect was induced by the Indomie noodles inclusion in the diets; hence the health status of the rats was okay ${ }^{[22]}$. There was a significant $(\mathrm{p}<0.05)$ increase in lymphocytes percentage, with a decrease of monocytes percentage and granulocytes percentage compared to the control group. Red blood cell indices examination showed a reduction in $\mathrm{MCV}, \mathrm{MCH}$ and $\mathrm{MCHC}$ values. This shows that the three levels of Indomie noodles (25, 50 and $75 \%$ ) in all blood parameters were different from the control values. The decrease in hemoglobin in the corpuscles is probably due to the impaired biosynthesis of haeme in the bone marrow ${ }^{[23]}$. An increase in platelet count in $75 \%$ compared to the control group possibly suggests secondary thrombocytosis. It was suggested this increase might be due to excessive intake of one of Indomie noodle and seasoning components (sodium and glutamate) that affect blood and body fluid compartments and water balance of the body. They also add that it could be related to the biosynthesis of the thrombopoietin hormone that stimulates the production of platelets ${ }^{[24]}$.

The result of this study showed that serum protein decreased as concentrations of Indomie noodles increased. Total protein was significantly $(p<0.05)$ reduced in both $50 \%$ and $75 \%$ group compared to control group rats. Concentrations of albumin, bilirubin and total protein in the blood can indicate the functional state of the liver ${ }^{[25]}$. Albumin in conjunction with other 
plasma proteins exerts a colloidal osmotic pressure, which serves to maintain a normal blood volume. Thus, the reduction in total protein concentration might be due to minimizing a synthetic function of the liver ${ }^{[26]}$. There was an insignificant increase $(p<0.05)$ in the concentration of total cholesterol, TGs and LDL-cholesterol with a reduction of HDL-cholesterol level at different percentages of Indomie noodles supplementation compared to control. The increase in the cholesterol concentration in the groups fed Indomie noodles is due to the absence of fiber in the formulated $\operatorname{diet}^{[27]}$ and due to diets high in fiber have the ability to bind cholesterol, because dietary fiber reduces the concentration of both cholesterol and triacylglycerols ${ }^{[28]}$.

ALT test activity is related to general hepatocellular and AST to mitochondrial damage. Serum levels of AST, ALT and ALP enzymes would increase due to its release. High serum levels of AST and ALT are usually indicative of liver deterioration in animals $^{[29]}$ and humans ${ }^{[30]}$. High ALP serum levels are probably due to damage to membrane permeability of hepatocytes, resulting in leakage of this enzyme into the bloodstream ${ }^{[31]}$.

Urea was significantly $(\mathrm{p}<0.05)$ increased in $25 \%, 50$ $\%$ and $75 \%$ compared to the control group while, serum creatinine was insignificantly increased compared to the control group because renal function indices are used to assess the normal functioning capacity of the different parts of the nephron ${ }^{[32]}$. Urea excretion by the kidney is the primary method of nitrogen excretion while creatinine, a catabolic product of muscle, is a useful index of assessing the functional capacity of the glomerular and tubular regions of the nephrons and low levels are seen in some types of liver disease and diets that are very low in protein ${ }^{[33]}$. Uric acid significantly $(p<0.05)$ decrease in $50 \%$ and $75 \%$ compared to control group because uric acid is the end product of the catabolism of tissue nucleic acid, purine bases metabolism ${ }^{[34]}$.

The effect of Indomie noodles in male reproductive capacity appears to be mostly unknown, but results of the present study demonstrate that graded concentrations of Indomie noodles had significant adverse effects on sperm concentration, motility and viability. In mammals, spermatogenesis is entirely dependent upon testosterone ${ }^{[35]}$; however, the only total abolition of testicular androgen action resulted in consistent azoospermia ${ }^{[36]}$. Androgens act to stimulate spermatogenesis through androgen receptors (ARs) located on Sertoli cells and peritubular myoid cells of the testis ${ }^{[37]}$. It has been demonstrated that androgen stimulation of spermatogenesis requires direct androgen action on the Sertoli cells ${ }^{[38]}$ and this was necessary for postmeiotic spermiogenesis $\left.{ }^{[36}\right]$. Thus, appropriate regulation of androgen activity via the hypothalamicpituitary-testis axis is necessary for the initiation and maintenance of spermatogenesis. The indication is that the reduced cauda epididymal sperm counts observed in the Indomie noodles treated rats may be the result of a considerable decline in the influence of testosterone on spermatogenesis in these rats.

The outcome of this study has shown that significant increases in platelet count, AST, ALP and blood urea values were determined while significant decreases in $\mathrm{MCH}, \mathrm{MCHC}$, total protein and serum uric acid values were observed in rats treated with Indomie noodles. However, with the consumption of Indomie noodles, significant decrease in sperm count, sperm motility and sperm viability were determined in rats treated with Indomie noodles. Also, Indomie noodles consumption could have adverse effects on the body weight, braintestes and liver-kidney weights of adult rats. This mean the Indomie noodles do not promote growth because it has low protein and high carbohydrate content.

\section{Conflicts of Interest:}

The authors declared no conflict of interest.

\section{REFERENCES}

1. Polpuech C, Chavasit V, Srichakwal P, Paniangvait P. Effects of fortified lysine on the amino acid profile and sensory qualities of deep-fried and dried noodles. Malays J Nutr 2011;17(2).

2. Ejembi D, Sanni M, Emmanuel FT, Abbah OC. Evaluation of the biochemical composition and proximate analysis of indomie noodle. Int J Med Appl Sci 2014;3(1):166-75.

3. Sanni ME, Emmanuel D, Friday T, Abbah O, Ogala E. Effects of chronic administration of indomie noodles on the activity of alanine aminotransferase of rat kidney. J Pharm Biomed Sci 2013;30(30):S65-71.

4. Ngah WS, Ariff NF, Hanafiah MA. Preparation, characterization and environmental application of crosslinked chitosan-coated bentonite for tartrazine adsorption from aqueous solutions. Water Air Soil Pollut 2010;206(1):225-36.

5. Moutinho IL, Bertges LC, Assis RV. Prolonged use of the food dye tartrazine (FD\&C yellow $\mathrm{n} \square 5$ ) and its effects on the gastric mucosa of Wistar rats. Braz J Biol 2007;67(1):141-5.

6. Loliger J. Function and importance of glutamate for savory foods. J Nutr 2000;130(4):915S-20S.

7. Onyema OO, Farombi EO, Emerole GO, Ukoha AI, Onyeze GO. Effect of vitamin E on monosodium glutamate induced hepatotoxicity and oxidative stress in rats. Indian J Biochem Biophys 2006;43(1):20-4.

8. Sharma A. Monosodium glutamate-induced oxidative kidney damage and possible mechanisms: a mini-review. J Biomed Sci 2015;22(1):1-6.

9. Onakewhor JU, Oforofuo IA, Singh SP. Chronic administration 
of monosodium glutamate induces oligozoospermia and glycoen accumulation in Wistar rat testes. Afr J Reprod Health 2017;2(2).

10. Oforofuo IA, Onakewhor JU, Idaewor PE. The effect of chronic administration of MSG on the histology of the adult Wistar rat testes. Bio Res Comm 1997;9(2):30-56.

11. Nayanatara AK, Vinodini NA, Damodar G, Ahemed B, Ramaswamy CR, Shabarianth M, et al. Role of ascorbic acid in monosodium glutamate mediated effect on testicular weight, sperm morphology and sperm count, in rat testis. J Chin Clin Med 2008;3(1):1-5.

12. Friedewald WT, Levy RI, Fredrickson DS. Estimation of the concentration of low-density lipoprotein cholesterol in plasma, without use of the preparative ultracentrifuge. Clin Chem 1972;18(6):499-502.

13. Abdulkareem SM, Nanakali NM. Quercetin reduces oxidative stress damage to reproductive profile induced by $2,3,7$, 8-tetrachlorodibenzo-p-dioxin in male albino rats (Rattus norvegicus L.). Appl Ecol Environ Res 2019;17(6):13185-97.

14. Feuston MH, Bodnar KR, Kerstetter SL, Grink CP, Belcak MJ, Singer EJ. Reproductive toxicity of 2-methoxyethanol applied dermally to occluded and nonoccluded sites in male rats. Toxicol Appl Pharmacol 1989;100(1):145-61.

15. Wells ME, Awa OA. New technique for assessing acrosomal characteristics of spermatozoa. J Dairy Sci 1970;53(2):227-32.

16. Abdulkareem SM, Nanakali NM. Ameliorating potential of quercetin on liver function, genotoxicity and oxidative damage induced by 2, 3, 7, 8-Tetrachlorodibenzo-P-Dioxin in liver of male rats. Pak J Zool 2020;52(2).

17. Park CS, Baik BK. Cooking time of white salted noodles and its relationship with protein and amylose contents of wheat. Cereal Chem 2004;81(2):165-71.

18. Moore KL, Dalley AF. Clinically oriented anatomy. Wolters kluwer India Pvt Ltd; 2018.

19. Anozie OI, Onwurah IN. Toxic effects of Bonny light crude oil in rats after ingestion of contaminated diet. Nig J Biochem Mol Biol 2001;16(3):1035-85.

20. Ijeh II, Obidoa O. Effects of dietary incorporation of two varieties of Vernonia amygdalina. Del leaves on relative organ weights of weaning albino rats. Nig J Biochem Mol biol $2001 ; 6$.

21. Johnson CE. Effects of fluid imbalances. Neurosciences in Medicine. New York, NY: JB Lippincott Company. 1995. p. 187-9.

22. Alabi OM, Aderemi FA, Ladokun AO, Lawal TE, Alabi OB, Afolabi KD. Blood profile of broiler finishers fed diet with graded levels of indomie noodle waste meal in humid tropics. Elixir Agric 2012;52:11269-72.

23. Aziz IA, Zabut BM. Alterations of blood indices associated with low-dose administration of methomyl insecticide for short times to albino rats. Egypt J Biol 2014;16:17-23.

24. Ajibola M, Oloruntoba AC, Chinomso UA, Shekins O. The effects of orally administered monosodium glutamate (MSG) on blood thrombocyte, blood coagulation and bleeding in rats. IOSR J Pharm Biol Sci 2012;4(1):1-5.
25. Ganong WF. Review of medical physiology. 17th ed. USA; Connecticut: Appleton \& Lange publishers; 1995. p. 781.

26. Adebayo JO, Igunnu A, Arise RO, Malomo SO. Effects of co-administration of artesunate and amodiaquine on some cardiovascular disease indices in rats. Food Chem Toxicol 2011;49(1):45-8.

27. Zailani HA, Umaru HA, Samuel G. Effects of instant noodles formulated diet on weanling albino rats. Direct Res J Agric Sci 2016;4(7):161-8.

28. Tai ES, Sim XL, Ong TH, Wong TY, Saw SM, Aung T, et al. Polymorphisms at newly identified lipid-associated loci are associated with blood lipids and cardiovascular disease in an Asian Malay population. J Lipid Res 2009;50(3):514-20.

29. Durak K, Bilgen OF, Kaleli T, Tuncel P, Ozbek R, Turan K. Antioxidant effect of $\alpha$-tocopherol on fracture haematoma in rabbits. J Int Med Res1996;24(5):419-24.

30. Ray DC, Drummond GB. Halothane hepatitis. Br J Anaesth 1991;67(1):84-99.

31. Bhushan B, Saxena PN, Saxena N. Biochemical and histological changes in rat liver caused by cypermethrin and beta-cyfluthrin. Arh Hig Rada Toksikol 2013;64(1):57-66.

32. Guyton AC, Hall JE. Textbook of medical physiology with student consult online access. $11^{\text {th }}$ ed. Philadelphia, PA: Elsevier Inc.; 2006. p. 859A864.

33. Go AS, Chertow GM, Fan D, McCulloch CE, Hsu CY. Chronic kidney disease and the risks of death, cardiovascular events and hospitalization. N Engl J Med 2004;351(13):1296-305.

34. Rinsler MG. Methods and techniques in clinical chemistry. J Clin Pathol 1973;26(6):461.

35. Wang RS, Yeh S, Tzeng CR, Chang C. Androgen receptor roles in spermatogenesis and fertility: lessons from testicular cell-specific androgen receptor knockout mice. Endocr Rev 2009;30(2):119-32.

36. Zhang FP, Pakarainen T, Poutanen M, Toppari J, Huhtaniemi I. The low gonadotropin-independent constitutive production of testicular testosterone is sufficient to maintain spermatogenesis. Proc Natl Acad Sci USA 2003;100(23):13692-7.

37. De Gendt K, Swinnen JV, Saunders PT, Schoonjans L, Dewerchin M, Devos A, et al. A Sertoli cell-selective knockout of the androgen receptor causes spermatogenic arrest in meiosis. Proc Natl Acad Sci USA 2004;101(5):1327-32.

38. O'shaughnessy PJ, Verhoeven G, De Gendt K, Monteiro A, Abel MH. Direct action through the Sertoli cells is essential for androgen stimulation of spermatogenesis. Endocrinology 2010;151(5):2343-8.

This is an open access article distributed under the terms of the Creative Commons Attribution-NonCommercial-ShareAlike 3.0 License, which allows others to remix, tweak, and build upon the work non-commercially, as long as the author is credited and the new creations are licensed under the identical terms

This article was originally published in a special issue,
"Trends in Therapeutic Management of Various Clinical
Conditions II" Indian J Pharm Sci 2021:83(2)Spl issue;195-203

